\title{
Evaluation of C-peptide in Type 2 Diabetic Patient in Douala Cameroon: C-peptide Correlation with BMI and Duration of Diabetes
}

\author{
Manta Diane ${ }^{1}$, Mbango-Ekouta Noel Désirée ${ }^{1,3}$, Nda Mefo'o Jean Pierre ${ }^{1,2}$, \\ Assiene Oyong Damase Serge ${ }^{1}$, Eloumou Bagnaka Servais ${ }^{1,3}$, Adiogo Dieudonné ${ }^{1}$ \\ ${ }^{1}$ Faculty of Medicine and Pharmaceutical Sciences, University of Douala, Douala, Cameroon \\ ${ }^{2}$ General Hospital of Douala, Douala, Cameroon \\ ${ }^{3}$ Gyneco-Obstetric and Pediatric Hospital of Douala, Douala, Cameroon
}

Email address:

oliviadavy@yahoo.com (M. Diane)

\section{To cite this article:}

Manta Diane, Mbango-Ekouta Noel Désirée., Nda Mefo'o Jean Pierre., Assiene Oyong Damase Serge, Eloumou Bagnaka Servais, Adiogo Dieudonné. Evaluation of C-peptide in Type 2 Diabetic Patient in Douala Cameroon: C-peptide Correlation with BMI and Duration of Diabetes. American Journal of Biomedical and Life Sciences. Vol. 9, No. 5, 2021, pp. 236-238. doi: 10.11648/j.ajbls.20210905.12

Received: August 2, 2021; Accepted: August 26, 2021; Published: September 11, 2021

\begin{abstract}
Introduction: The C-peptide assay is the more reliable indicator of insulin secretion than insulin itself, making it possible to optimize the treatment and to anticipate the evolution of complications linked to type 2 diabetes. The present study reports the relationship between the levels of C-peptide, the body mass index and the duration of type 2 diabetes in two hospitals (General Hospital and Gyneco-Obstetric and Pediatric Hospital) in the city of Douala Cameroon. The aim of this study was to assess relationship between serum C-peptide levels with some patient characteristics such as duration in type 2 diabetes and obesity. Methods: We carried out an analytical cross-sectional study over a period of 9 months of patients with type 2 diabetes regularly monitored at the General Hospital and Gyneco-Obstetric and Pediatric Hospital of Douala Cameroon. We included any patient whose diagnosis of type 2 diabetes was mentioned in the medical file. The C-peptide assays after fasting blood sampling were carried out according to the principle of electro-chemiluminescence assay. The ANOVA and PEARSON tests made it possible to compare groups and look for correlations between C-peptide and other variables. The significant threshold was set at $\mathrm{P}<0.05$. Results: We included 90 subjects with a mean age of $58 \pm 12.31$ years. The average BMI was $28.18 \pm 5.51 \mathrm{~kg} / \mathrm{m}^{2}$. The mean duration of diabetes was $8.71 \pm 6.94$ years, the mean C-peptide level was $2.50 \pm 1.68 \mathrm{ng} / \mathrm{ml}$. We found that C-Peptide levels increased with body mass index $(\mathrm{P}=0.004)$ and patient age $(\mathrm{P}=0.004)$. Conversely, we found that $\mathrm{C}$-peptide levels increased with duration of diabetes but not significantly $(\mathrm{P}=0.411)$. Conclusion: The C-peptide levels make it possible to objectify the residual secretion of pancreatic beta cells. We found that C-peptide levels increases with increasing body mass index, but they were no significant correlation between C-peptide levels and the diabetes duration.
\end{abstract}

Keywords: C-peptide, Type 2 Diabetes, Douala

\section{Introduction}

Diabetes is a serious chronic disease that occurs when the pancreas does not make enough insulin, or when the body is unable to use the insulin it produce properly [1]. Type 2 diabetes is a disease associated with obesity and sometime genetics and environmental facts [2, 3]. It is linked to peripheral insulin resistance which can be produced in greater than normal quantity and which, overtime, could be reduced, thus leading to a modification of the therapeutic approach [4-8]. The insulin endogenous secretory reserves in patients with type 2 diabetes is usually assessed through Cpeptide assay which is considered more reliable indicator of insulin secretion than insulin itself $[9,10]$. As it gives an idea about the residual beta cell mass, it may help to decide the type of therapies for each patient [8]. For example, some studies have shown that, Patients with low c-peptide levels receiving insulin had better clinical outcomes than those with normal to high levels and receiving insulin [11].

There are very few studies done on C-peptide in 
Cameroonian type 2 diabetics. The present study was undertaken to assess relationship between serum C-peptide levels with some patient characteristics such as duration in type 2 diabetes and obesity.

\section{Methodology}

We conducted an analytical cross-sectional study over a 9month period from October 1, 2017 to June 30, 2018 on patients with type 2 diabetes. We recruited patients based on selection of medical records of interest and during consultations at the diabetologist.

We included any type 2 diabetic patient regularly monitored and agreeing to participate in the study and we excluded cases of secondary and gestational diabetes, any type 2 diabetic patient with acute or chronic renal failure or on dialysis, presenting with Cushing's syndrome or documented pancreatitis or insulinoma.

The body mass index (BMI) was calculated using the formula $\mathrm{BMI}=$ Weight $(\mathrm{Kg}) \div \operatorname{Height}^{2}(\mathrm{~m})$ and the weight status determined according to WHO rules [12]. The fasting $\mathrm{C}$-peptide assays were carried out according to the principle of electrochemiluminescence assay on Cobas E411 and the standard thresholds were those indicated on the leaflet used for the assay (C-peptide elecsys for Cobas e411: low values $<1.1 \mathrm{ng} / \mathrm{mL}$, normal values $1.1-4.4 \mathrm{ng} / \mathrm{mL}$, high values $>4.4$ $\mathrm{ng} / \mathrm{mL})[13]$.

The ANOVA and PEARSON tests made it possible to compare groups and look for correlations between the $\mathrm{C}$ peptide and other variables. The significant threshold was set at $\mathrm{P}<0.05$.

\section{Results}

Our study population consisted of 90 subjects, 50 of whom were females and 40 were males. The average age was $58.5 \pm$ 12.31 years, the extreme ages 29 to 84 years.

Table 1. Correlation C-peptide levels with ages of patients.

\begin{tabular}{llllll}
\hline \multirow{2}{*}{ Ages (years) } & \multicolumn{2}{l}{ C-peptide levels ng/ml } & \multicolumn{2}{c}{ C-peptide means } & \multicolumn{2}{c}{ Pearson Corrélation } \\
\cline { 2 - 6 } & $<\mathbf{1 , 1}$ & $\mathbf{1 , 1 - 4 , 4}$ & $>\mathbf{4 , 4}$ & $\mathbf{n g} / \mathbf{m l}$ & $\mathbf{r}$ \\
\hline$\leq 30$ & 0 & $1(100 \%)$ & 0 & $1,14 \pm 0,0$ & \\
{$[31-50]$} & $5(31,25 \%)$ & $10(62,50 \%)$ & $1(6,25 \%)$ & $1,58 \pm 1,04$ & 0,301 \\
$\geq 50$ & $11(15,07 \%)$ & $50(68,49 \%)$ & $12(16,44 \%)$ & $2,72 \pm 1,73$ & 0,004 \\
\hline
\end{tabular}

$\mathrm{r}=$ Pearson coefficient, $\mathrm{P}=\mathrm{P}$-value.

Analysis of Table 1 shows that C-peptide increases with the age of the patient. From our results, 17.8\% of the study population secreted an amount below the C-peptide reference values and $14.4 \%$ above the reference values. Low secretion is relatively higher in subjects between the ages of 31 and 50 years compared to other age groups.

Table 2. Correlation C-peptide levels with duration of diabetes, and BMI.

\begin{tabular}{|c|c|c|c|c|c|c|c|}
\hline & & \multicolumn{3}{|c|}{ C-peptide levels ng/ml } & \multirow{2}{*}{ C peptide means } & \multicolumn{2}{|c|}{ ANOVA test } \\
\hline & & $<1,1$ & $1,1-4,4$ & $>4,4$ & & $\mathbf{F}$ & $\mathbf{P}$ \\
\hline \multirow{3}{*}{ Duration of diabetes (years) } & $<5$ & $5(16,67 \%)$ & $21(70,00 \%)$ & $4(13,33 \%)$ & $2,28 \pm 1,37$ & \multirow{3}{*}{0,898} & \multirow{3}{*}{0,411} \\
\hline & $5-10$ & $5(17,25 \%)$ & $21(72,41 \%)$ & $3(10,34 \%)$ & $2,39 \pm 1,58$ & & \\
\hline & $\geq 10$ & $6(19,35 \%)$ & $19(61,30 \%)$ & $6(19,35 \%)$ & $2,82 \pm 2,03$ & & \\
\hline \multirow{3}{*}{ BMI } & $<18,5$ & $1(100 \%)$ & 0 & 0 & $0,30 \pm 0,00$ & \multirow{3}{*}{4,729} & \multirow{3}{*}{0,004} \\
\hline & $18,5-24,9$ & $6(23,07 \%)$ & $19(73,08 \%)$ & $1(3,84 \%)$ & $2,04 \pm 1,13$ & & \\
\hline & $25-30$ & $6(17,14 \%)$ & $25(71,43 \%)$ & $4(11,43 \%)$ & $2,20 \pm 1,44$ & & \\
\hline
\end{tabular}

$\mathrm{F}=$ ANOVA coefficient; $\mathrm{P}=\mathrm{P}$-value; threshold $0.05, \mathrm{MHD}=$ hygiene-dietetic measures.

Analysis of Table 2 shows that C-peptide levels increase significantly with body mass index (BMI), and the increase in C-peptide levels with duration of diabetes is not significant.

\section{Discussion}

The average patient was over weight $(\mathrm{BMI}=28.18 \pm 5.51)$ and we noted a positive correlation between C-peptide levels, BMI and patient ages $(\mathrm{P}=0.004)$. The same fact was reported by studies carried out on type 2 diabetics by SONWANE in 2018 [14] in India, THUNANDER in 2012 [15] in Sweden, and INUKAI [16] in 1999 in Germany. This could be explained by the fact that obesity is associated with increase in insulinresistance, so to overcome this insulinresistance, there is more insulin secretion leading to increase C-peptide levels. However, despite showing initial high C-peptide levels, obese subjects showed a rapid decline in B-cell function: Significant contributors to the decline rate of C-peptide levels were the high BMI and fasting plasma glucose levels [17]. Thus, in over weight type 2 diabetics, it is necessary to first focus on dietary measures, physical activities and oral antidiabetic in order to reduce overweight, insulinresistance, and sensitize cells to insulin. The decrease in C-peptide secretion could be related to poor glycemic control, a worsening of the pathology leading to a weight loss, a consequence of insufficient care because it is not suited to the context of modification of the secretion of insulin.

In our study, the increase in C-peptide levels with duration 
of diabetes was not significant $(\mathrm{P}=0.411)$. This same observation was reported by RAMAZAN SARI [18] in Turkey. However, a study made on the pancreas from subjects with long standing type 2 diabetes showed that the decrease in insulin secretion over time is characteristic of type 2 diabetes. in fact, regulation of beta cell mass involves a balance between beta-cell replication and apoptosis. However the beta cell loss by apoptosis appears to play a major role in the progression of the disease [19].

\section{Conclusion}

The C-peptide levels make it possible to objectify the residual secretion of pancreatic beta cells. We found that $\mathrm{C}$ peptide levels increases with increasing body mass index, but they were no significant correlation between C-peptide levels and the diabetes duration.

\section{References}

[1] Organisation Mondiale de la santé Rapport mondial sur le diabète, 2016.

http://apps.who.int/iris/bitstream/10665/254648/1/978924256 5256-fre.pdf?ua=1 (consulté le 24/09/2017).

[2] Sauvanet J. P, Sheen A. J, Ziegler O., Drouin P., « insulino sensibilité, surcharge pondérale et diabète de type 2 » Diabetes Metab, 2001, 27, cahier 2, 189-293.

[3] Léonel Soyeux et al. «effet of immigration in France on type 2 diabetes mellitus risk» 8 december 2003, p 31 .

[4] Chan W. B., Chan J. C., Chow C. C., Young V. T., So W. Y., Li J. K., and al. Glycaemic control in type 2 diabetes: the impact of body weight, beta-cell function and patient education QJM 2000; 93: 183-190.

[5] Polonsky K. S. Lilly lecture 1994 . The $\beta$-cell in diabetes: from molecular genetics to clinical research Diabetes 1995; 44: 705-717.

[6] J. HAZARD, L. PERLEMUTER. Endocrinologie (ABREGES), 2e édition MASSON Paris New York Barcelone Milan Mexico Sao Paulo 1983. p 551.

[7] Zhou S, Meng X, Wang S, Ren R, Hou W, Huang K et al. A 3- year follow up study of B-cell function in patients with early-onset type 2 diabetes; Experimental and therapeutic medicine 2016; 12: 1097-102.
[8] Siraj ES, Reddy SSK, Scherbaum WA, Abdulkadir J, Hammel JP, Faiman C. Basal and postprandial c-peptide levels in Ethiopians with diabetes. Diabetes care 2002; 25 (3): 453-7.

[9] Chowta MN, Adhikari PM, Chowta NK, Shenoy AK, D'Souza S. Serum c-peptide level and renal function in diabetes mellitus. Indian Journal of Nephrology, 2010; 20 (1): 25-27.

[10] Beliakin SA, Serebrennikov VN, Shklovskii BL, Patsenko MB. C-peptide as an early diagnostic of metabolic syndrome and indicator of cardiovascular disease in patients with type 2 diabetes mellitus. Voen Med Zh 2014; 335 (10): 46-9.

[11] Gary TCK et al. Effects of interactions between c-peptide levels and insulin treatment on clinical outcomes among patients with type 2 diabetes mellitus. CMAJ 2009; 180 (9): 919-926.

[12] www.inpes.sante.fr- le disque de calcul de l'indice de masse corporel chez l'adulte.

[13] www.roche.com: notice C-peptide Elecsys 2013-11, V 9.0 English.

[14] Anand Sonwane, L. Romesh Sharma, Santa Naorem, Lallan Prasad, Salam Ranabir; Fasting c-peptide level and its correlation with body mass index and duration of diabetes in type 2 diabetes.

[15] Thunander M, Torn C, Peterson C, Ossiansson B, Fornander J, Landin-Olsson M. Levels of C-peptide, BMI, and age, and their utility for classification of diabetes in relation to autoimmunity, in adults with newly diagnosed diabetes in Kronoberg, Sweden. Eur J Endocrinol 2012; 166: 1021-1029.

[16] Inukai T, Matsutomo R, Tayama K, Aso Y, Takemura Y. Relation between the serum level of C-peptide and risk factors for coronary heart disease and diabetic microangiopathy in patients with type-2 diabetes mellitus. Exp Clin Endocrinol Diabetes 1999; 107: 40-45.

[17] Nakayama H, Kato T, Nakayama S, Kaku H, Muraishi K, Tokubuchi I, Hara K et al. Cross sectional and longitudinal analysis of factors contributing to the progressive loss of the beta cell function in type 2 diabetes mellitus. Intern Med 2015; 54 (16): 1971-6.

[18] Sari R, Balci MK. Relationship between C peptide and chronic complications in type-2 diabetes mellitus. J Natl Med Assoc 2005; 97: 1113-1118.

[19] Zangeneh F, Arora PS, Dyck PJ, Bekris L, Lernmark A, Achenbach SJ. Effects of duration of diabetes on insulin secretion. Endocr. Pract. 2006; 12 (4): 388-393. 